\title{
Early reconstitution of haematopoiesis after allogeneic bone marrow transplantation: a prospective histopathological study of bone marrow biopsy specimens
}

\author{
$\mathrm{H}$ van den Berg, $\mathrm{Ph} M$ Kluin, J M Vossen
}

\begin{abstract}
To study early haematopoietic reconstitution after bone marrow transplantation bone marrow biopsy specimens taken in the third week after transplantation were evaluated. Cellularity was highly variable; localisation of the various cell lineages and the ratios of myeloid cells to erythroid cells were abnormal. Clustering of cells of the same lineage in the same stage of maturation was prominent. The bone marrow stroma showed many anomalies, including increased fibre content, periodic acid Schiff positivity of fat cells, oedema, sinus ectasia and granulomas. A comparison of biopsy findings with clinical and laboratory data showed a correlation between the amount of erythroid cells and the day of appearance of reticulocytes, as well as the number of reticulocytes. Absence of clustering of haematopoietic cells in four of five patients was associated with either failure of engraftment or early leukaemic relapse. Variables such as infections and administration of possibly myelosuppressive drugs did not influence bone marrow biopsy findings.
\end{abstract}

Only a few reports mentioning the histological changes in the bone marrow after transplantation have been published, ${ }^{1-9}$ and these studies have concerned themselves with bone marrow biopsy specimens taken at various times from day 14 after bone marrow transplantation onwards. To obtain further insight into the phenomena of engraftment, rejection, and leukaemic relapse, which may influence the eventual outcome of the allogeneic bone marrow transplantation, a prospective histological study of bone marrow biopsy specimens was performed in consecutively transplanted patients. In an earlier retrospective study of bone marrow biopsy specimens taken early and late after bone marrow transplantation in adult and paediatric graft recipients, we described heterogeneous histological findings. ${ }^{7}$ We did not find any correlation between peripheral haematological reconstitution and bone marrow histology. In the present study bone marrow biopsies were performed in all paediatric transplant recipients in the third week after transplantation. This period was chosen because the retrospective study had shown that in the first two weeks following transplantation cellularity may have been too low for evaluation. Week 3 therefore seemed to provide the most information. To look for possible differences in repopulation kinetics, biopsy specimens of all patients, irrespective of the original disease and composition of the graft were included. Histological findings were correlated with peripheral haematological findings, possible complications after bone marrow transplantation, such as infections and graft-versushost disease (GvHD), and administration of possibly myelosuppressive drugs.

\section{Methods}

From 1986 to 198824 infants and children consecutively received transplantations for various diseases in the bone marrow transplantation unit of the paediatric department of Leiden University Hospital. Five patients were excluded because they were not evaluable for different reasons, such as critical clinical condition (respiratory insufficiency) not permitting a biopsy $(n=2)$, massive sclerosis of the bone marrow in an infant with osteopetrosis $(n=1)$, loss of the biopsy specimen in the laboratory $(n=1)$, and biopsy specimen not evaluable because it consisted mainly of cartilage $(n=1)$. The characteristics at diagnosis and follow up of the 19 patients are given in tables 1 and 2 . Of the six patients with (severe) combined immune deficiency disease ((S)CID), including two patients with HLA class II deficiency, five had no HLA identical donor; these five patients received $T$ cell depleted grafts. The other patients had HLA identical donors and they received full bone marrow grafts. All patients except for case 11 received marrow ablative conditioning (table 1 ). The mean graft size was $2.9 \times 10^{8}$ nucleated bone marrow cells per $\mathrm{kg}$ of recipient body weight (range $0.6 \times$ $10^{8}$ up to $5.0 \times 10^{8}$ nucleated cells). $\mathrm{T}$ cell depletion was performed either by albumingradient centrifugation followed by E-rosette sedimentation, ${ }^{10}$ or, immunologically, by either Campath-1M or Campath-1G monoclonal antibodies and complement lysis.

After bone marrow transplantation cyclosporin A or methotrexate, or both, were used for prophylaxis of GvHD except for three
Department of Paediatrics

Accepted for publication

4 January 1990 
Table 1 Characteristics at diagnosis and subsequent treatment

\begin{tabular}{|c|c|c|c|c|c|c|c|c|c|}
\hline Patients & $\begin{array}{l}\text { Donor HLA- } \\
\text { identical }\end{array}$ & $\begin{array}{l}\text { Cyclo- } \\
\text { phosphamide } \\
120 \mathrm{mg} / \mathrm{kg}\end{array}$ & $\begin{array}{l}\text { Cyclo- } \\
\text { phosphamide } \\
200 \mathrm{mg} / \mathrm{kg}\end{array}$ & $\begin{array}{l}\text { Busulphan } \\
16 \mathrm{mg} / \mathrm{kg}\end{array}$ & $\begin{array}{l}\text { Metho- } \\
\text { trexate } \\
24 \mathrm{mg}\end{array}$ & $\begin{array}{l}\text { Cytosin- } \\
\text { arabinoside } \\
60 \mathrm{mg}\end{array}$ & $\begin{array}{l}\text { Total body } \\
\text { irradiation } \\
>5 G y\end{array}$ & $\begin{array}{c}\text { Total body } \\
\text { irradiation } \\
<5 G y\end{array}$ & $\begin{array}{l}\text { Campath } \\
1 \text { and } 2\end{array}$ \\
\hline 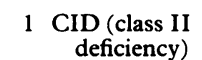 & No & + & & & & & & + & + \\
\hline 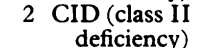 & No & & + & + & & & & & + \\
\hline 3 ALL II & Yes & + & & & & + & + & & \\
\hline $\begin{array}{l}4 \text { Thalassaemia } \\
5 \text { ALL II }\end{array}$ & $\begin{array}{l}\text { Yes } \\
\text { Yes }\end{array}$ & + & + & + & + & & + & & \\
\hline 6 NHL II & Yes & + & & & + & & + & & \\
\hline 7 RAEB & Yes & + & & & & & + & & \\
\hline 8 ALL II & Yes & + & & & + & & + & & \\
\hline 9 AML I & Yes & + & & & + & & + & & \\
\hline 10 ALL II & Yes & + & & & + & & + & & \\
\hline 11 SCID & No & & & + & & & & & \\
\hline 12 SCID & No & + & & + & & & & & \\
\hline $\begin{array}{l}13 \text { AML I } \\
14 \text { CID }\end{array}$ & Yes & + & & & + & & + & & \\
\hline $\begin{array}{l}14 \text { CID } \\
15 \text { ALL II }\end{array}$ & Yes & t & + & + & & & 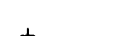 & & \\
\hline $\begin{array}{l}15 \text { ALL II } \\
16 \text { Thalassaemia }\end{array}$ & $\begin{array}{l}\text { Yes } \\
\text { Yes }\end{array}$ & t & t & + & t & & + & & \\
\hline $\begin{array}{l}\text { Thalassaemia } \\
17 \text { Thalassaemia }\end{array}$ & Yes & & t & $\begin{array}{l}T \\
+\end{array}$ & & & & & \\
\hline 18 SCID & No & & + & + & & & & & \\
\hline 19 AML I & Yes & + & & & + & & + & & \\
\hline
\end{tabular}

(S)CID: (severe) combined immune deficiency disease; ALL: acute lymphoblastic leukemia; AML: acute myeloblastic leukemia; NHL: non-Hodgkin's lymphoma; RAEB: refractory anaemia with excess of blasts; I/II: first or second complete remission.

recipients of 2-3 $\log \mathrm{T}$ cell depleted bone marrow, who received no GvHD prophylaxis (cases 1,2, and 11 in table 1). Data on variables possibly influencing the bone marrow recovery after transplantation were collected-(potential) myelosuppressive drugs, such as methotrexate, co-trimoxazole, flucytosin, and corticosteroids. The presence of GvHD and, if applicable, date of onset of GvHD, the presence of fever as well as clinical manifestations or microbiological findings indicative for viral, bacterial, or fungal infection were also registered. Data of peripheral blood values such as haemoglobulin concentration, leucocyte, granulocyte, thrombocyte and reticulocyte counts, date of appearance of reticulocytes, and date of last thrombocyte and erythrocyte transfusions were recorded.

\section{BONE MARROW BIOPSY SPECIMENS}

Biopsy specimens were obtained with a Jamshidi biopsy needle ${ }^{11}$ between 14 and 20 days after transplantation, according to a protocol approved by the human ethical research committee of Leiden University Hospital. The biopsy specimens were embedded in methylmethacrylate and handled as described before. ${ }^{12}$ Scoring of the bone marrow biopsy specimens was performed independently by two investigators ( $\mathrm{HvdB}$ and $\mathrm{PK}$ ) using a precoded checklist comprising several variables of haematopoiesis and stromal texture, as described previously. ${ }^{7}$ In short, cellularity, the localisation of the different cell lineages, such as central $v$ paratrabecular, the ratio of erythroid $v$ myeloid cells, the stage of maturation of haematopoietic cells, and the presence or absence of dyserythropoiesis were scored. The cellularity of individual cell lineages was calculated from the general cellularity multiplied by the proportion of relevant cell types. When the biopsy specimen was taken, bone marrow was aspirated for in vitro culturing of myeloid and erythroid precursor cells, such as CFUGM, CFU-E, and BFU-E, according to Iscove. ${ }^{13}$

For statistical analysis of possible correlations between different variables of haematological reconstitution, the Spearman rank test was used, and for correlation between clinical data and histological findings the $\chi^{2}$ test with Yates' correction was used.

Table 2 Characteristics at diagnosis and outcome

\begin{tabular}{|c|c|c|c|c|}
\hline Patients & Engraftment & $\begin{array}{l}\text { GvHD } \\
\text { grade } \geqslant I I\end{array}$ & $\begin{array}{l}\text { Date of relapse } \\
\text { of leukaemia } \\
\text { (years after } \\
\text { transplantation) }\end{array}$ & $\begin{array}{l}\text { Follow up } \\
\text { (years) }\end{array}$ \\
\hline $\begin{aligned} 1 & \text { CID (class II deficiency) } \\
2 & \text { CID (class II deficiency) } \\
3 & \text { ALL II } \\
4 & \text { Thalassaemia } \\
5 & \text { ALL II } \\
6 & \text { NHL II } \\
7 & \text { RAEB } \\
8 & \text { ALL II } \\
9 & \text { AML I } \\
10 & \text { ALL II } \\
11 & \text { SCID } \\
12 & \text { SCID } \\
13 & \text { AML I } \\
14 & \text { CID } \\
15 & \text { ALL II } \\
16 & \text { Thalassaemia } \\
17 & \text { Thalassaemia } \\
18 & \text { SCID } \\
19 & \text { AML I }\end{aligned}$ & $\begin{array}{l}\text { No (autologous reconstitution) } \\
\text { No (autologous reconstitution) } \\
\text { Complete } \\
\text { Complete } \\
\text { Complete } \\
\text { Complete } \\
\text { Complete } \\
\text { Complete } \\
\text { Complete } \\
\text { Complete } \\
\text { Partial } \\
\text { Partial } \\
\text { Complete } \\
\text { Complete } \\
\text { Complete } \\
\text { Rejection/autologous reconstitution } \\
\text { Complete } \\
\text { Partial } \\
\text { Complete }\end{array}$ & $\begin{array}{l}- \\
\overline{+} \\
- \\
- \\
- \\
- \\
- \\
- \\
- \\
+ \\
+ \\
- \\
- \\
- \\
- \\
- \\
-\end{array}$ & $\begin{array}{l}\frac{1}{2} \\
\text { 14 } \\
\text { NA } \\
\text { NA } \\
\text { NA } \\
\text { NA } \\
\text { NA } \\
\text { NA }\end{array}$ & $\begin{array}{l}2 \frac{1}{2} \\
2 \frac{1}{2} \\
3 \\
2 \frac{1}{2} \\
1 \frac{1}{4} \text { (died) } \\
2 \frac{1}{2} \\
2 \frac{1}{2} \\
2 \\
1 \frac{1}{2} \\
1 \frac{3}{4} \text { (died) } \\
1 \\
1 \\
1 \\
1 \frac{3}{4} \\
1 \\
1 \frac{3}{4} \\
1 \\
1 \frac{1}{4} \\
\frac{3}{4}\end{array}$ \\
\hline
\end{tabular}

(S)CID: (severe) combined immune deficiency disease; ALL: acute lymphoblastic leukemia; AML: acute myeloblastic leukemia; NHL: non-Hodgkin's lymphoma; RAEB: refractory anaemia with excess of blasts; I/II: first or second complete remission. NA: not applicable. 
Figure 1 Biopsy specimen taken at day 14 from a patient transplanted for acute showing focal differences in cellularity. lymphoblastic leukaemia

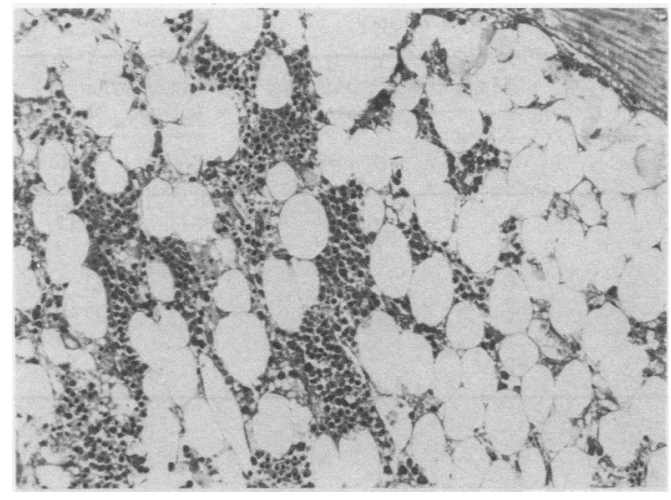

\section{Results}

Cellularity in the biopsy specimens of the 19 recipients showed a large range from $0-90 \%$. In patients with haematological malignancies $(n=10)$ it ranged from 0 to $80 \%$ (mean $37 \%$ ), in those with thalassaemia $(n=3)$ it ranged from 30 to $90 \%$ (mean $53 \%$ ), in those with (S)CID $(n=6)$ it ranged from 30 to $90 \%$ (mean $64^{\circ}{ }_{0}$ ). The localisation of the haematopoietic cells in the subcortical and central areas and within the intertrabecular areas was highly variable, irrespective of the original disease (fig 1). In the biopsy specimens of seven patients haematopoiesis was localised in the centre of the intertrabecular areas; in those of three patients localisation was paratrabecular; in the others the cells were equally distributed over the interosseous space. In normal bone marrow biopsy specimens erythroid haematopoiesis is localised mainly centrally and myeloid haematopoiesis near the endostium; this correlation was not found in biopsy specimens in the third week after transplantation (fig 2). In three patients only a few erythroid cells were seen and the ratio between erythroid and myeloid cells was very low; in the specimens of 16 other children the ratio ranged between $1: 3$ and 4:1 Decreased erythropoiesis was not associated with the patient's original disease. In all patients the erythroid outgrowth was in the form of clusters of cells in the same stage of maturation (fig 3), except for one thalassaemic patient; in that biopsy specimen clusters of erythroid cells in different maturation stages were present as is seen in healthy subjects. In the biopsy specimens of nine of the 19 patients erythroid cells consisted only of immature stages-two with acute lymphoblastic leukaemia, one with acute myeloblastic leukaemia, one with thalassaemia, five with (S)CID.

Figure 2 Biopsy specimen taken at day 14 from a patient transplanted for acute lymphoblastic leukaemia showing a cluster of granulopoiesis and cluster of erythropoiesis in the central part of the intertrabecular area.

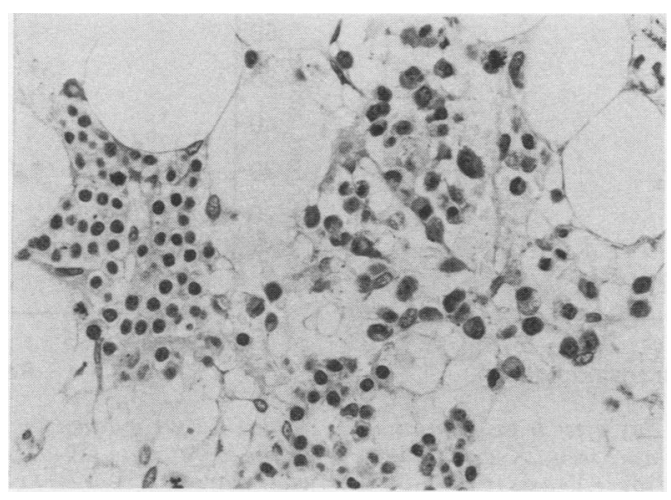

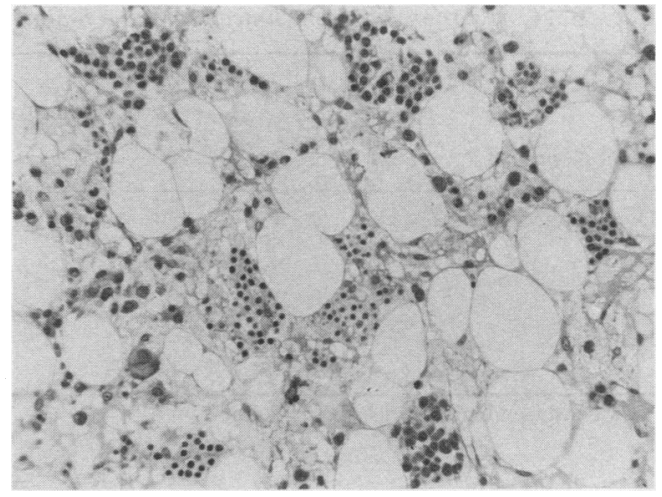

Figure 3 Biopsy specimen taken at day 14 from a patient transplanted for acute lymphoblastic leukaemia showing several synchronised clusters of erythroid and granulocytic cells in different stages of maturation.

Immature myelopoiesis was localised along the endostium in six cases, as can be seen in normal haematopoiesis; in the other cases granulopoiesis was abnormally localised-that is, more prominent in the central parts of the intertrabecular space. In 11 patients there was outgrowth to mature granulocytes; in the remaining eight patients only immature cell types were seen. In the latter biopsy specimens the localisation of the granulocyte precursors was also abnormal-that is, in the central intertrabecular space. Clustering of cells in the same stage of maturation was seen in all specimens (fig 3), except for five patients. Two of them had autologous reconstitution. In 11 out of 19 biopsy specimens, pronounced eosinophilia was seen. Megakaryocytes, seen in 16 specimens, were normally localised-that is, in the central parts of the intertrabecular area. An abnormal finding was that megakaryocytes were present in clusters in nine biopsy specimens, which contrasts with the normally scattered localisation of megakaryocytes.

With regard to the bone marrow stroma in the biopsy specimens the following abnormalities were noted: increased numbers of reticulin fibres in eight cases, small granulomas consisting of macrophages and fibroblast like cells in two cases, PAS positivity of fat cells in 11 cases, oedema in nine patients and sinusectasias in 11 cases. A substantial increase in iron containing macrophages was noted in the biopsy specimens of thalassaemic patients.

\section{CLINICOPATHOLOGICAL CORRELATIONS}

Possible correlations between biopsy findings, clinical data (engraftment, rejection, relapse, GvHD, infections and drug treatment), and variables of haematopoiesis (peripheral blood values and number of precursor cells in bone marrow cultures) were evaluated. We did not find any association between qualitative and quantitative aspects of the biopsy specimens and engraftment, rejection, and relapse of leukaemia after transplantation (table 3 ). There were no distinct differences in the biopsy findings in relation to HLA matching of recipient and donor, $T$ cell depletion of the graft, and type of preparative treatment of the patient before bone marrow transplantation. It was striking that of five patients in whose biopsy specimens clustering of myelopoiesis 
Table 3 Correlations between clinical data and findings of bone marrow histopathology

\begin{tabular}{|c|c|c|c|c|c|c|c|c|c|c|}
\hline \multirow[b]{2}{*}{ Clinical outcome } & & \multirow{2}{*}{$\begin{array}{l}\text { Patients } \\
\text { (n) }\end{array}$} & \multicolumn{2}{|c|}{ Cellularity } & \multicolumn{2}{|c|}{ Myeloid:erythroid ratio } & \multicolumn{2}{|c|}{$\begin{array}{l}\text { Localisation of } \\
\text { haematopoietic cells }\end{array}$} & \multicolumn{2}{|c|}{$\begin{array}{l}\text { Clustering of myeloid } \\
\text { precursors }\end{array}$} \\
\hline & & & $\geqslant 50^{\circ} \%$ & $<50 \%$ & $(1-2,3)$ & Abnormal & Normal & Abnormal & Present & Absent \\
\hline Donor engraftment & $\begin{array}{l}\text { Yes } \\
\text { No }\end{array}$ & $\begin{array}{r}17 \\
2\end{array}$ & $\begin{array}{l}7 \\
1\end{array}$ & $\begin{array}{r}10 \\
1\end{array}$ & $\begin{array}{l}7 \\
1\end{array}$ & $\begin{array}{r}10 \\
1\end{array}$ & $\begin{array}{l}0 \\
0\end{array}$ & $\begin{array}{r}17 \\
2\end{array}$ & $\begin{array}{r}14 \\
0\end{array}$ & $\begin{array}{l}3 \\
2\end{array}$ \\
\hline Rejection & $\begin{array}{l}\text { Yes } \\
\text { No }\end{array}$ & $\frac{1}{16^{\star}}$ & $\begin{array}{l}1 \\
7\end{array}$ & $\begin{array}{l}0 \\
9\end{array}$ & $\begin{array}{l}0 \\
7\end{array}$ & $\begin{array}{l}1 \\
9\end{array}$ & $\begin{array}{l}0 \\
0\end{array}$ & $\begin{array}{r}1 \\
16\end{array}$ & $\begin{array}{r}0 \\
14\end{array}$ & $\begin{array}{l}1 \\
2\end{array}$ \\
\hline Relapse & $\begin{array}{l}\text { Yes } \\
\text { No }\end{array}$ & $\begin{array}{l}3 \\
7\end{array}$ & $\begin{array}{l}1 \\
2\end{array}$ & $\begin{array}{l}2 \\
5\end{array}$ & $\begin{array}{l}1 \\
2\end{array}$ & $\begin{array}{l}2 \\
5\end{array}$ & $\begin{array}{l}1 \\
1\end{array}$ & $\begin{array}{l}2 \\
6\end{array}$ & $\begin{array}{l}2 \\
7\end{array}$ & $\begin{array}{l}1 \\
0\end{array}$ \\
\hline
\end{tabular}

*Two children had no engraftment (table 1)

was absent, three had (early or late) autologous reconstitution and the fourth patient had early relapse of leukaemia in autologous cells-six months after transplantation. Numbers of cells administered in the graft, use of (potential) myelosuppressive drugs (methotrexate, cotrimoxazole, and flucytosin), method of GvHD prophylaxis, fever, and presence of bacterial or viral infections were not reflected in bone marrow biopsy specimen findings.

The haematopoiesis in the bone marrow was compared with the variables on peripheral haematological recovery, such as absolute numbers of blood leucocytes and granulocytes and time of appearance of reticulocytes in the blood; the day of the last thrombocyte transfusion was also taken as a measure of recovery of megakaryopoiesis. No correlation was found for bone marrow and peripheral blood variables in terms of recovery of granulopoiesis and megakaryopoiesis, but a correlation was found between the score of erythropoiesis in the bone marrow and the day of first appearance of reticulocytes ( $\mathrm{rS}-0.57$ ), as well as the percentage of reticulocytes at the date of biopsy ( $\mathrm{rS}$ +0.63 ) (figs 4 and 5). No correlation was found between colony counts for CFU-GM (range 120-4530 colonies per million Ficoll separated cells), CFU-E (range 0-8600 colonies), BFU-E (range 0-4120 colonies) and bone marrow cellularity, qualitative characteristics of the bone marrow biopsy specimens, number of granulocytes, reticulocytes, and day of appearance of reticulocytes. The in vitro CFU formation after bone marrow transplantation showed high variability with figures above and below the limit for normal, as found in our own laboratory and as described by several authors. ${ }^{14-16}$ The culture findings will be described in more detail separately.

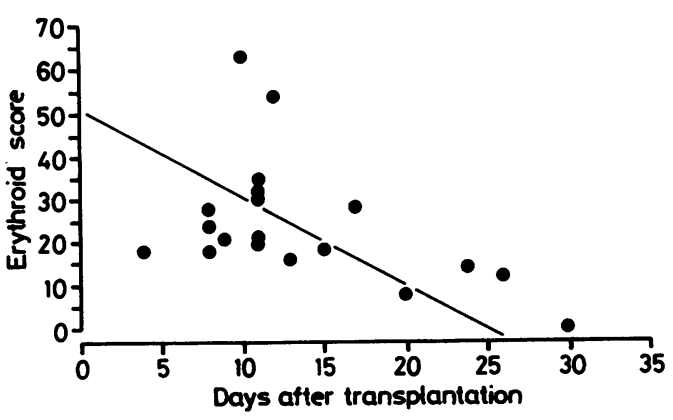

Figure 4 Graph showing the day after transplantation at which the first reticulocytes were seen (X-axis) $v$ the at which the first reticulocytes were seen ( $X$-axis) $v$ the
erythroid score in the bone marrow (Y-axis); rS $-0,57$.

\section{Discussion}

The histopathological findings of bone marrow biopsy specimens, obtained in the third week after allogeneic bone marrow transplantation, showed a great variability both in qualitative and in quantitative aspects. This agrees with the results of our earlier retrospective study, ${ }^{7}$ in which it was found that stabilisation occurred one month after bone marrow transplantation. There is evidence that outgrowth of grafted committed progenitor cells is responsible for the bone marrow findings soon after bone marrow transplantation ${ }^{2717}$; proliferation and differentiation from pluripotent stem cells takes place at a later stage.

We could not find a positive correlation between variables for haematopoiesis in the bone marrow and those for recovery of peripheral blood values, except for the red blood cell lineage. The obvious explanation for this finding is that the half life of white cells in peripheral blood is much shorter-that is, in the order of hours to a few days-than that of red blood cells. Possibly after bone marrow transplantation the half life of granulocytes, monocytes, and lymphocytes in the blood is even shorter than normally found-for example, by an increased extravasation, pooling, and consumption in the spleen, the gut, or the lungs. We could not confirm the findings of Niederwieser et $a l^{18}$ - that there is a correlation between the numbers of nucleated cells in the graft and the appearance of reticulocytes. It is not surprising that the quantitative variables of haematopoiesis in the bone marrow did not correlate with the numbers of colonies in short term in vitro cultures. Besides the finding of a large variability of these quantitative data on in vitro cultures, the outgrowth of haematopoietic progenitors is also artifically supported by a

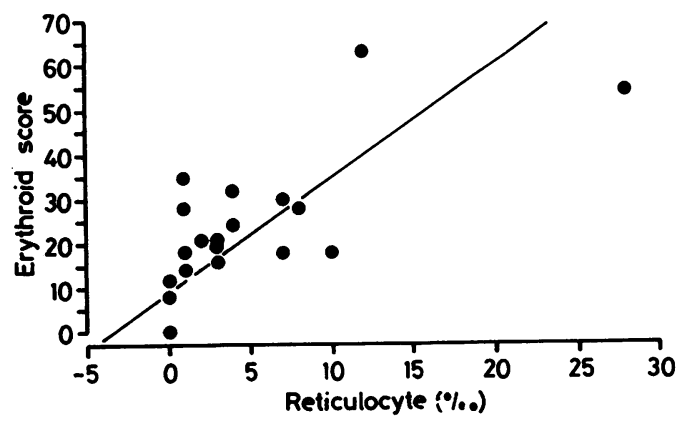

Figure 5 Graph showing the promillage of reticulocytes at the biopsy date ( $X$-axis) and the erythroid score in the bone marrow ( $Y$-axis); $r S+0,63$. 
medium containing several poorly defined growth factors.

As to the correlation with major clinical events such as rejection, autologous reconstitution, and early leukaemic relapse, the only relevant finding in our opinion, was the absence of clustering of myeloid precursors in the bone marrow biopsy specimens in five infants and children from whom four either had autologous reconstitution or an early leukaemic relapse. This contrasted strongly with the findings in the 14 other children in whom no failure of engraftment was seen, and in only two cases was there leukaemic relapse at a later date. The clustering of myeloid precursors, a finding characteristic of the early post-transplantation period and probably indicating the outgrowth of committed myeloid progenitors, may be indicative of proper engraftment; in early autologous reconstitution recovery does not solely originate from committed progenitor cells. This finding needs to be confirmed in a larger number of patients.

Changes in the bone marrow stroma, such as oedema, fibrosis, and the formation of granulomas $^{4-9}$ were less prominent in this series of early bone marrow biopsy specimens than in a previous series of specimens. ${ }^{7}$ In this study many patients did not receive cytostatic treatment before conditioning for bone marrow transplantation; this may in part explain the difference because it has been shown that intensive chemotherapy and irradiation are associated with an increase in content of reticulin fibres in the bone marrow. ${ }^{1920} \mathrm{Graft}$ versus-host disease has been found to be responsible for stroma changes, such as granuloma formation in the bone marrow of rodents, after mismatched bone marrow transplantation. ${ }^{21}$ We could not confirm such a correlation but we noted that acute GvHD of $\geqslant$ grade II was observed only in three recipients (case 3 following matched, and cases 11 and 12 following mismatched, bone marrow transplantation). Other variables such as infections and administration of possibly myelosuppressive drugs after transplantation did not influence the bone marrow biopsy findings.

Campath monoclonal antibodies were kindly provided by Drs Waldman and Hale, Cambridge, England.
1 Arnold R, Calvo W, Heymer B, Schmeiser T, Heimpel H, Kubanek B. Extramedullary haemopoiesis after bone marrow transplantation. Scand J Haematol 1985;34:9-12.

2 Cline M, Gale RP, Golde DW. Discrete clusters of hemopoietic cells in the marrow cavity of man after bone marrow transplantation. Blood 1977;50:709-12.

3 Heymer B, Kruger G, Arnold R, et al. GVH reaction and morphology of bone marrow after allogeneic bone marrow transplantation. In: Lennert K, Hubner K, eds. Pathology of the bone marrow. Stuttgart: Gustaf Fischer Verlag, 1984:281-5.

4 Sale GE. Pathology of bone marrow with bone marrow transplantation. In: Sale GE, Shulman HM, eds. The pathology of bone marrow transplantation. New York: pathology of bone marrow transplan

5 Naeim F, Smith GS, Gale RP. Morphologic aspects of bone marrow transplantation in patients with aplastic anemia. Hum Pathol 1978;9:295-308.

6 Snover DC, Filipovich AH, Ramsay NKC, Weisdorf SA Kersey JH. Graft versus host disease like histopathologic findings in pre-bone marrow transplantation patients with severe T cell deficiency. Transplantation 1985;39:95-7.

7 Van den Berg H, Kluin PhM, Zwaan FE, Vossen JM. Histopathology of bone marrow reconstitution after allogeneic bone marrow transplantation. Histopathology 1989;15:363-73.

8 Rajantie J, Gale GE, Deeg HJ, et al. Adverse effects of severe marrow fibrosis on hematologic recovery after chemoradiotherapy and allogeneic bone marrow transplantation Blood 1986;67:1693-7.

9 Muller-Hermelink HK, Sale GE. Pathological findings in human bone marrow transplantation. In: Lennert $\mathrm{K}$ Hubner K, eds. Pathology of the bone marrow. Stuttgart: Gustaf Fischer Verlag, 1984:255-79.

10 Wagemaker G, Heidt PJ, Merchav S, Van Bekkum DW. Abrogation of histocompatibility barriers to bone marrow transplantation in rhesus monkeys, In: Baum SD, Ledney GD, Thierfelder S, eds. Experimental hematology today. GD, Thierfelder S, eds. Exper

11 Te Velde J, Ottolander GJ den, Haak HL, et al. Iliac bone marrow trephine biopsy: some remarks on the technique. Neth J Med 1978;21:221-7.

12 Te Velde J, Burkhardt R, Kleiverda K, Leenheers-Binnendijk L, Sommerfeld W. Methylmethacrylate as embedding medium in histopathology. Histopathology 1977 1:319-30.

13 Iscove NN, Senn J, Till JE, McCulloch EA. Colony formation by normal and leukemic human marrow cells in culture: Effect of conditioned medium from human leukocytes. Blood 1971;37:1-5.

14 Arnold R, Heit W, Schmeiser T, et al. Reconstitution of haemopoiesis after bone marrow transplantation. Exp Hematol 1984;12(suppl 15):116-17.

15 Arnold R, Schmeiser T, Heit W, et al. Hemopoietic reconstitution after bone marrow transplantation. Exp Hematol 1986;14:271-7.

16 Ma DDF, Varga DE, Biggs JC. Haemopoietic reconstitution after allogeneic bone marrow transplantation in man recovery of haemopoietic progenitors (CFU-Mix, BFU-E and CFU-GM). Br J Haematol 1987;65:5-10.

17 Cronkite EP, Inoue T, Bullis JE. Bone marrow cells other than stem-cells seed the bone marrow after the rescue of fatally irradiated mice. Exp Hematol 1987;15:1168-70.

18 Niederwieser D, Gratwohl A, Oberholzer M, et al. Bone marrow cell dose and kinetics of recovery following allogeneic marrow transplantation in man. Blut 1983; 47:355-60.

19 Brody JP, Krause JR, Penchansky L. Bone marrow response to chemotherapy in acute lymphocytic leukemia and acute non-lymphocytic leukemia. Scand J Haematol 1985; 35:240-5.

20 Islam A, Catovsky D, Goldman JM, Galton DAG. Bone marrow fiber content in acute myeloid leukemia before marrow fiber content in acute myeloid leukemia befo

21 Hirabayashi N. Studies of graft versus host (GvHD) reactions. I. Impairment of hemopoietic stroma in mice suffering from $\mathrm{GvH}$ disease. Exp Hematol 1981;9:101-10. 